\title{
Research Article \\ MICROBES FROM COFFEE PULP WASTE AND THEIR PECTINOLYTIC ENZYME ACTIVITY FOR BIODEGRADATION
}

\author{
SANTOSHREDDY MACHENAHALLI, RANJINI A.P., GIRI MADHU S., SUDHA M. AND DAIVASIKAMANI S. \\ Division of Plant Pathology, Central Coffee Research Institute, C. R. Station, 577117, Chikkamagaluru, Karnataka, India \\ *Corresponding Author: Email-santosh3881@gmail.com
}

Received: March 23, 2018; Revised: March 27, 2018; Accepted: March 28, 2018; Published: March 30, 2018

\begin{abstract}
Degradation of coffee pulp waste is time taken process. The microorganisms isolated from coffee pulp waste could be used as catalysts in the biodegradation of pulp waste which reduces the composting period. An experiment was conducted in which coffee pulp waste was collected from Central Coffee Research Institute farm and isolated two Aspergillus spp. (Asp.1 and Asp.2) two Trichoderma spp. (Tri.1 and Tri.2) and two-gram negative bacteria (CPB-1 and CPB-2). These isolated microbes were subjected to pectinolytic enzyme activity assay by plate assay method. Clear zone of pectinolytic enzyme activity was observed in Aspergillus spp., Trichoderma spp. and CPB-1 bacterium isolate whereas clear zone was not observed in CPB-2 bacterium isolate.
\end{abstract}

Keywords- Coffee pulp waste, Pectinolytic enzyme, Aspergillus spp., Trichoderma spp.

Citation: Santoshreddy Machenahalli, et al., (2018) Microbes from Coffee Pulp Waste and Their Pectinolytic Enzyme Activity for Biodegradation. International Journal of Microbiology Research, ISSN: 0975-5276 \& E-ISSN: 0975-9174, Volume 10, Issue 3, pp.-1109-1110. DOl: http://dx.doi.org/10.9735/0975-5276.10.3.1109-1110

Copyright: Copyright@2018 Santoshreddy Machenahalli, et al., This is an open-access article distributed under the terms of the Creative Commons Attribution License, which permits unrestricted use, distribution and reproduction in any medium, provided the original author and source are credited.

\section{Introduction}

Coffee occupies a place of pride among plantation crops grown in India. Coffee fruits are economically important part of the coffee plant. After harvesting, the coffee berries are transported to the coffee processing unit where they are dumped into a tank of water to remove spoiled or green fruit and foreign material, which rise to the surface. Basically, coffee fruit processing is to obtain the commercial beans consist of two operations. The first is a wet processing step yielding coffee pulp, mucilage, and waste waters on the one hand, and coffee beans with hulls on the other; the second operation is a dry processing step that separates the hulls from the coffee beans. Coffee pulp is the first product obtained during wet processing, and it represents on a dry-weight basis about $29 \%$ of the weight of the whole berry [4]. In coffee industry coffee pulp is a serious disposal problem. Pollution awareness and policies have played a minor role in finding uses for coffee pulp as availability of the product has been of paramount importance. Because, coffee is grown for the bean, this defines the economy of its production. But the rational utilization of coffee processing by-products, in particular coffee pulp, also has some economic implications that may become evident as their use is increased. From the point of view of the total energy input going into coffee cultivation, including the cost of the land, the utilization of byproducts will make the whole process more efficient. Coffee pulp is rich in carbohydrates, protein, minerals, pectin and tannin which favours the rapid growth of microorganisms [9]. Coffee pulp and husk are the major contributors of environmental pollution from the coffee estates [1,5]. Coffee pulp containing waste water is often discharged to the surrounding water bodies resulting in contamination of fresh water [7]. Caffeine is one of the major agro industrial wastes generated from the coffee and tea processing units and these wastes are often released into the water bodies. Caffeine is most toxic and anti physiological component of coffee pulp. The presence of caffeine in soil affect soil fertility as it inhibits coffee seed germination and growth of seedlings [11]. Therefore, decaffeination of waste is necessary from the point of view of environmental conservation [5,14]. Recycling of coffee pulp waste for composting is time taken process. The use of microorganisms as catalysts in the biodegradation of organic compounds reduces the composting period [12,13]. There is need to develop microbial consortium for effective composting of coffee pulp waste. The present study was undertaken to isolate, identify and characterize the microbes present in the coffee pulp waste and assess their pectinolytic enzyme activity to utilize them as an effective bio-degraders.

\section{Materials and methods \\ Isolation of microbes from coffee pulp waste by serial dilution method \\ Coffee pulp waste was collected for isolation of microbes from pulping unit of Central Coffee Research Institute (CCRI), Blehonnuru, Chikkamagaluru District, Karnataka State, India. Coffee pulp was ground in sterile pestle and mortar and made into slurry using sterile distilled water. An aliquot of this sample was drawn and serially diluted with dilution blanks and plated on potato dextrose agar medium [2]. After incubation, the isolated fungal cultures were purified and characterized by morphological observations [3].}

\section{Plate assay method to detect pectinolytic enzyme activity}

Plate assay was carried out by inoculating pectin agar medium having $1 \%$ pectin with pure cultures of fungi separately. The inoculated plates were incubated for about $72 \mathrm{hr}$. at room temperature. After the colonies developed around 3 to $4 \mathrm{~mm}$ diameter, iodine potassium iodide solution was added to detect the clear zone [15].

\section{Results and Discussion}

Coffee pulp is a relatively rich source of sugars and its use for microbial growth is of interest; hence the present study was carried out in Central Coffee Research Institute. From the coffee pulp waste collected at CCRI pulping unit, two Aspergillus spp.(Asp.1 and Asp.2) two Trichoderma spp. (Tri.1 and Tri.2) and two 
gram negative bacteria (CPB-1 and CPB-2) were isolated and characterized. These isolated microbes were subjected to pectinolytic enzyme activity assay by plate assay method as explained in materials and methods. The results are presented in [Table-1].

Table-1 Pectinolytic enzyme activity of microbes isolated from coffee pulp waste

\begin{tabular}{|c|c|}
\hline $\begin{array}{c}\text { Coffee pulp waste } \\
\text { microbes }\end{array}$ & $\begin{array}{c}\text { Pectinolytic enzyme } \\
\text { activity }\end{array}$ \\
\hline Aspergillus (Asp. 1) & + \\
\hline Aspergillus (Asp. 2) & + \\
\hline Trichoderma (Tri. 1) & + \\
\hline Trichoderma (Tri. 2) & + \\
\hline Bacterium CPB - 1 & + \\
\hline Bacterium CPB - 2 & + \\
\hline
\end{tabular}

't' Presence of pectinolytic enzyme activity; '-' absence of pectinolytic enzyme activity

Clear zone of pectinolytic enzyme activity was observed in Aspergillus spp., Trichoderma spp. and CPB-1 bacterium isolate whereas clear zone was not observed in CPB-2 bacterium isolate. Among the 14 bacteria and fungi isolated from coffee pulp waste and upon screening, Pseudomonas fluorescens, Trichoderma reesei and Phanerocheatum chrysosporium were found better to develop a microbial consortium for effective composting of coffee pulp waste [10]. Bui, (2014) revealed that microorganisms isolated from coffee exocarp in natural environment to aid in biodegradation of coffee pulp waste at coffee-producing areas in Vietnam. Coffee pulp is a relatively good substrate for Aspergillus oryzae, Bacillus megatherium and Saccharomyces carevisae [6].

Application of research: The leads from the present study will help to develop microbial consortium for effective coffee pulp waste degradation and enhancement of compost.

Research Category: Enzyme technology

Acknowledgement / Funding: Author thankful to Central Coffee Research Institute, C. R. Station, 577117, Chikkamagaluru, Karnataka

*Principle Investigator: Dr Santoshreddy Machenahalli Institute: Central Coffee Research Institute, C. R. Station, 577117, Chikkamagaluru, Karnataka

Research project name or number: Isolation, identification and screening of microbes from coffee pulp waste

\section{Author Contributions: All author equally contributed}

Author statement: All authors read, reviewed, agree and approved the final manuscript

\section{Conflict of Interest: None declared}

Ethical approval: This article does not contain any studies with human participants or animals performed by any of the authors.

\section{References}

[1] Adams M.R. and Dougan J. (1981) Trop Sci, 123, 178-196.

[2] Aneja K.R. (2012) Experiments in Microbiology, Plant Pathology and Biotechnology. New Age International (P) limited, New Delhi. pp. 607.

[3] Barnett H.L. (1960) Illustrated genera of imperfect fungi, second edition, Burgees publishing company, Minneapolis, Minn. pp.52 and 62.

[4] Braham J.E. and Bressani R. (1979) Coffee pulp: Composition, technology and utilization. Published by International Development Research Centre, Ottawa, Canada, p. 9.

[5] Bressani R. (1979a) Potential uses of coffee berry by-products. In: Coffee pulp: Composition, technology and utilization, publication 108, edited by Braham J. E. and Bressani R. (International Development Research
Centre, Ottawa, Canada), 14.

[6] Bressani R. (1979b) Anti-physiological factors in coffee pulp. In:Coffee pulp: Composition, technology and utilization, publication 108, edited by Braham, J. E. and Bressani R. (International Development Research Centre, Ottawa, Canada), 83-88.

[7] Buerge I.J., Poiger T., Muller M.D. and Buser H.R. (2003) Environ Sci Technol, 37, 691-700.

[8] Bui B.H. (2014) Int. J. Recycl. Org. Waste. Agri., 3, 48.

[9] Damodaran A. (1978) Indian Coffee, 62, 22-25.

[10] Divakaran J. and Elango R. (2009) Glob. J. Env. Res., 3 (2), 92-95.

[11] Friedman J. and Waller G. R. (1983) J. Chem. Ecol, (9), 1099-1106.

[12] Jyotsna K.P., Vijayalakshmi K., Prasanna N.D. and Shaheen S.K. (2010) Int. J. Life. Sci., 6, 325-327.

[13] Opatokun S.A., Kabbashi N., Alam M.Z.,Salihu A.,Abass A. andRuqayyah T.L.D. (2011) Afr. J. Biotechnol. 10:18800-18806.

[14] Roussos S., Hannibal L., Aquiahuatla M. A., Hernandez T. M. R. and Marakis S. (1994) J. Food. Sci. Technol., 31,316-319.

[15] Soares M.N. C., Da Silva and Gomes R. (1999) Rev. Microbiol., 30, 299303. 